- FINANSE I PRAWO FINANSOWE.

- Journal of Finance and Financial Law $•$

Wrzesień/September 2018 • vol. 3(19): 55-65

https://doi.org/10.18778/2391-6478.3.19.05

\title{
OCENA ZMIAN W ZAKRESIE CEN TRANSFEROWYCH W POLSCE I ICH WPŁYW NA OBOWIAZZKI PODATNIKÓW
}

Karol Przydatek

Uniwersytet Marii Curie-Skłodowskiej

\begin{abstract}
Streszczenie
W ostatnim czasie miały miejsce duże zmiany w zakresie cen transferowych zwiększające wymogi dokumentacyjne wielu przedsiębiorstw. Jak każde zmiany prawne, mają one przynieść określone efekty. Historia cen transferowych w Polsce sięga już pierwszej połowy dwudziestego wieku i można zauważyć sukcesywny rozwój przepisów w ich zakresie. Ostatnio wprowadzone przepisy dotyczące cen transferowych przyczyniły się do zmiany zakresu obowiązków dla poszczególnych grup podatników. W niniejszej pracy zostaną poddane analizie zmiany w zakresie cen transferowych i ich wpływ na obowiązki podatników.
\end{abstract}

Słowa kluczowe: system podatkowy, ceny transferowe, ochrona podatników.

JEL Class: $\mathrm{H} 2$. 


\section{WPROWADZENIE}

Funkcjonujący system podatkowym w danym państwie pełni określone funkcje. Tematyka cen transferowych poruszana w polskich ustawach od wielu lat jest przedmiotem szczególnego zainteresowania organów podatkowych i rosną wymagania odnoszące się do zakresu wymaganej dokumentacji. Ma to uzasadnienie, szczególnie w związku z rosnącą globalizacją handlu. Hipotezą badawczą artykułu jest twierdzenie, że zmiany przepisów cen transferowych w Polsce wywierają określony wpływ na obowiązki podatników. Celem pracy jest próba oceny zmian $\mathrm{w}$ zakresie cen transferowych i ich wpływ na obowiązki polskich podatników. W poniższym artykule dokonana zostanie analiza efektów ekonomicznych zmian wprowadzonych w cenach transferowych w 2017 roku i ich przełożenie na obowiązki podatników.

\section{ISTOTA SYSTEMU PODATKOWEGO ORAZ CEN TRANSFEROWYCH}

Wszystkie państwa starają się rozwijać i skracać dystans społeczny we wszystkich sektorach gospodarki [Galwas i in. 2013: 46]. Pomaga im w tym konstruowany przez władze system podatkowy. Jest to zespół podatków funkcjonujących równocześnie $\mathrm{w}$ danym państwie, tworząc całość $\mathrm{w}$ sensie prawnym, jak również ekonomicznym. Jako zbiór przepisów prawnych, a także instytucji finansowych ustanawiających podatki oraz określających je zajmują się ich poborem. Istotnym jest, by system podatkowy jako podstawowy dochód budżetu państwa, funkcjonował poprawnie i sprawie, gdyż wiąże się to $\mathrm{z}$ wpływem na rozwój danego kraju. Budżet państwa dzięki systemowi podatkowemu ma możliwość realizacji jego funkcji redystrybucyjnej. Możliwe jest to poprzez ulgi oraz zwolnienia podatkowe, zróżnicowane stawki podatkowe oraz progresywne opodatkowanie dochodów. Redystrybucja dochodu oraz majątku narodowego między podatnikami i organami publiczno-prawnymi jest możliwa dzięki funkcjonującym podatkom. Od struktury funkcjonującego systemu podatkowego zależy zakres redystrybucji dochodów. Realizacja zadań społecznych, obronnych oraz oświatowych jest możliwa dzięki przemieszczaniu dochodów do budżetu poszczególnych jednostek publicznych.

W literaturze często podkreślane jest, że podatki mają charakter bezzwrotny, nieodpłatny, przymusowy [Rosiński 2010: 87]. Wiąże się to z najbardziej istotną, czyli fiskalną funkcją podatków. Powstały one bowiem w celu pokrywania publicznych wydatków [Możyłowski 2007: 23]. Za cel ich funkcjonowania postawiono dostarczanie jak najwyższych wpływów do wybranego budżetu. Funkcja fiskalna odnosi się do polityki społecznej, ekonomicznej, a także róż- 
nych form podziału dochodu narodowego. O konstrukcji podatków w głównej mierze przesądza cel fiskalny.

Podatki funkcjonujące w Polsce należy postrzegać jako logicznie funkcjonującą całość tworzącą system podatkowy [Czubakowska i Grodzińska 2013: 22]. Funkcjonowanie spójnego i logicznego systemu podatkowego umożliwia wzięcie pod uwagę postulatów ekonomicznych [Bylicki 2016: 289], a także prawnych, które dotyczą struktury, przejrzystości oraz wewnętrznej spójności aktów prawnych składających się na system podatkowy. Odpowiednia konstrukcja, a także koherentność z innymi przepisami obowiązującymi w kraju, umożliwiają zapewnienie większej efektywności pobieranych podatków. W związku $\mathrm{z}$ tym konieczne jest jednoczesne koncentrowanie się na wszystkich $\mathrm{z}$ funkcjonujących podatków w celu maksymalizacji ich skuteczności.

Organy państwowe podejmują również decyzje wybierając podstawę opodatkowania oraz zarządzają systemem podatkowym. Państwa, gdzie samorządy osiągnęły samodzielność, stosują inny system podatkowy niż w innych krajach. Kształt systemu podatkowego zależy od warunków ekonomicznych poszczególnych gospodarek. Można je podzielić na wysoko oraz słabo rozwinięte.

Kraje mają również możliwość stosowania system ulg i zwolnień [Szołno-Koguc 2016: 170]. Mniej obciążony zysk umożliwia generowanie dodatkowych środków finansowych, które przedsiębiorstwa mogą przeznaczyć na nowe inwestycje i rozwój, zwiększanie zatrudnienia, a tym samym zwiększanie dochodów budżet państwa. Ulgi podatkowe mogą zachęcać do podejmowania pewnych decyzji przez podatników. Władze państwowe myślące o przyszłości i zdrowiu przyszłych pokoleń mogą decydować się na stosowanie ulg na podejmowanie inwestycji proekologicznych. Ulgi i zwolnienia powodują jednak, że podatnicy, którzy nie mają możliwości skorzystania z nich mogą odczuwać niesprawiedliwość ich funkcjonowania. W związku z tym konieczne jest ostrożne ustalanie celem osiągnięcia zamierzonych celów oraz ograniczenia oporów społecznych.

System podatkowy ma swoje gospodarcze znaczenie, a rozwój gospodarki narodowej jest kształtowany w dużej mierze przez niego. Wzrost gospodarczy w wypadku zbyt dużych podatków może zostać zahamowany, ponieważ powoduje to ograniczenie wydatków przez społeczeństwo oraz zmniejszenie popytu. Również dodatkowe obowiązki podatkowe, np. prowadzenie ewidencji i składanie deklaracji utrudniają funkcjonowanie podatnikom. Zbyt częste zmienianie przepisów podatkowych może wywołać nieporozumienia pomiędzy władzami państwowymi oraz podatnikami [Podatki w Polsce, 2017: 4]. Skuteczne ich stosowanie pozwala więc na realizację zadań publicznych przez władze państwowe. 


\section{HISTORIA PRZEPISÓW DOTYCZĄCYCH CEN TRANSFEROWYCH W POLSKIM SYSTEMIE PODATKOWYM}

Ceny transferowe to takie ceny, po których towary, dobra niematerialne, a także usługi są przekazywane przez przedsiębiorstwo podmiotom powiązanym. Podmiotami powiązanymi mogą być przedsiębiorstwa wchodzące w skład grupy kapitałowej oraz filie, oddziały i zakłady. Zjawisko to może być wykorzystywane celem minimalizacji obciążeń podatkowych, a ceny te mogą różnić się od tych ustalonych przy porównywalnych transakcjach zawartych przez podmioty niepowiązane, ponieważ ceny te nie były negocjowane na wolnym rynku. Istotą cen transferowych jest to, że są interdyscyplinarnym narzędziem ekonomicznym, które służy zarządzaniu przedsiębiorstwami międzynarodowymi w wielu aspektach [Sojak 2016: 147]. Co ważne, ceny transferowe nie obejmują tylko światowych gigantów, ale również mniejsze przedsiębiorstwa, które posiadają oddział lub filię w innym kraju niż główna siedziby.

Duża zmienność to określenie, którym wyróżnia się polski system podatkowy. Jej przyczyny są złożone i mogą to być zarówno powody odnoszące się do realizacji zadań fiskalnych [Gomułowicz 1989: 56] przez podatki, ale również realizacja pewnych zadań społecznych. Zmiany w funkcjonowaniu przepisów dotyczących cen transferowych w Polsce miały miejsce przynajmniej trzy razy.

W latach dwudziestych miała miejsce pierwsza $\mathrm{z}$ nich, gdy przystąpiono do unifikacji systemu podatkowego. Po tym okresie wprowadzono do polskiego systemu pierwsze informacje dotyczące cen transferowych. Nowelizacja ustawy o państwowym podatku dochodowym została znowelizowana w 1935 roku i zawarto w niej pierwszy przepis dotyczący cen transferowych brzmiący następująco:

W art. 21 dodaje się ustępy 5 i 6 treści następującej: „Jeżeli osoba prawna pozostająca $\mathrm{w}$ bezpośrednim lub pośrednim związku gospodarczym $\mathrm{z}$ osobą mającą siedzibę lub miejsce zamieszkania za granicą tak układa bieg swoich interesów, że dzięki temu związkowi uzależniającemu jedną z tych osób od drugiej lub będącemu szczególnie korzystnym dla osoby, mającej siedzibę lub miejsce zamieszkania za granicą wcale nie wykazuje zysków albo też wykazuje zyski mniejsze od tych, jakich by należało oczekiwać, gdyby wspominany związek nie istniał, wówczas dochód podatkowy danej osoby prawnej należy ustalić bez uwzględnienia obciążeń szczególnych wynikających z powyższego związku.

Jeżeli przewidziane $\mathrm{w}$ ustępie piątym ustalenie kwoty dochodu na podstawie ksiąg handlowych natrafia na trudności, wówczas dochód będzie ustalony na podstawie obrotu przy zastosowaniu norm średniej zyskowności dla przedsiębiorstw takiego samego lub podobnego rodzaju" [Ustawa z dnia 18 marca 1935 r. .... 
Powyższy przepis miał przede wszystkim na celu odpowiednie zabezpieczenie interesu państwa i jego celów fiskalnych związanych z koniecznością pokrycia jego gwałtownie rosnących potrzeb w odniesieniu do sytuacji gospodarczej państwa po wojnie.

Regulacje stosowane po wojnie także w pewnym stopniu zajmowały się tematem obrotu międzynarodowego oraz reagowały na różnice $\mathrm{w}$ systemach podatkowych wpływające na podstawę opodatkowania w polskich przedsiębiorstwach. W 1946 r. w dekrecie o podatku dochodowym zawarto dodatkowe informacje odnoszące się do cen transferowych. W porównaniu z przepisami obowiązującymi $\mathrm{w}$ okresie międzywojennym $\mathrm{w}$ art. 17 dekretu rozszerzono pojęcie „osoby prawnej” do „podatnika”, dodano ustęp traktujący, iż w przypadku trudności ustalenia dochodu na podstawie ksiąg handlowych dochód będzie ustalony na podstawie innych dochodów, a także możliwości szacunku dochodu podatnika, w sytuacji, gdy jeden z powiązanych podmiotów w transakcji korzysta z ulg podatkowych lub warunków, które w znaczącym stopniu odbiegają od stosowanych norm w czasie i miejscu, gdy transakcja ma miejsce [Dekret z dnia 8 stycznia 1946 r. ...]. Powyższe zmiany pozwoliły na łatwiejsze funkcjonowanie podmiotów pozwalając im na większy wybór pod kątem stosowanych metod ustalania dochodów. Jednocześnie administracja państwowa uniemożliwiała podmiotom gospodarczym stosowanie agresywnej polityki podatkowej poprzez obniżanie kwoty podatku do zapłacenia $\mathrm{z}$ wykorzystywaniem podmiotów stosujących ulgi.

Nadanie podatkom roli adekwatnej do tej spełniającej w gospodarce kapitalistycznej było wynikiem zmiany ustroju gospodarczego w Polsce. Najistotniejsze było ponowne nadanie podatkom charakteru konfliktowego między państwem oraz obywatelem na tle dochodowym, ponieważ sprzyja to ustaleniu akceptowalnej przez podatników wysokości ciężarów podatkowych nakładanych przez suwerena [Owsiak 2016: 16].

Szczególnie istotna była reforma systemu podatkowego w latach 90., ponieważ była konsekwencją zmiany gospodarki centralnie planowej w gospodarkę rynkową.

Polskie prawo podatkowe zawdzięcza swoją formę przede wszystkim:

Zmianom gospodarczym mającym miejsce w 1989 roku związanym z reformą systemu podatkowego w Polsce

Rozpoczęcie w XXI wieku procesu harmonizacji przepisów podatkowych obowiązujących w Polsce z prawem UE, szczególnie w zakresie podatków bezpośrednich oraz pośrednich [Bylicki 2016: 289].

Wprowadzenie podatku dochodowego od osób fizycznych (w 1991 roku) oraz podatku dochodowego od osób prawnych (w 1992 roku) były efektem reformy systemu podatkowego w 1989 roku. Wtedy też w gospodarce rynkowej ponownie zainteresowano się problematyką cen transferowych. Ustawa o podat- 
ku dochodowym od osób prawnych zawierała art. 11 mówiący, że dochód podatnika pozostającego $\mathrm{W}$ związku gospodarczym z osobą mającą siedzibę za granicą układający bieg swoich interesów tak, iż nie wykazuje dochodów albo wykazuje dochody mniejsze od tych, jakich należałoby oczekiwać, gdyby wymieniony związek nie istniał, ustala się bez uwzględnienia obciążeń szczególnych, wynikających z powyższego związku. Jeżeli nie jest to możliwe, dochód ustalany jest w drodze oszacowania. Przepis ten stosowano, gdy podatnik wykorzystywał swój związek gospodarczy z osobą, której przysługują szczególne ulgi w podatku dochodowym, albo też wykonując świadczenie dla innego podatnika na warunkach rażąco korzystniejszych i odbiegających od ogólnie stosowanych norm w czasie i miejscu wykonywania świadczenia, przerzucając całość lub część swego dochodu na osobę korzystającą z ulg bądź innego podatnika i wskutek tego nie wykazując dochodu w takiej wysokości, jakiej należałoby oczekiwać, gdyby wymieniony związek nie istniał lub gdyby wymienione świadczenie nie zostało wykonane [Ustawa z dnia 15 lutego 1992 r. ...]. Z czasem artykuł ten był coraz bardziej rozwijany.

W roku 1996 zaczęto dostosowywanie prawa obowiązującego w Polsce do międzynarodowych regulacji celem stania się członkiem Organizacji Współpracy Gospodarczej i Rozwoju. Zmiany odnosiły się również do cen transferowych, przynosząc Wytyczne Ministra Finansów w sprawie określenia sposobu i trybu ustalania dochodów $\mathrm{w}$ drodze oszacowania i znaczące rozwinięcie art. 11 [Ustawa z dnia 21 listopada 1996 r. ...]. Wprowadzono powiązania bezpośrednie oraz pośrednie, powiązania związane z zarządzaniem lub kontrolą podmiotu, powiązania rodzinne, metody szacowania dochodów, a także warunki w wyniku których stosuje się szacowanie dochodów w tym wcześniej stosowany artykuł odnośnie wykorzystywania ulg o tym samym znaczeniu, lecz innym brzmieniu. $\mathrm{W}$ jednym z ustępów artykułu zawarto również informację, że poprzez powiązania kapitałowe uznaje się podmioty, które posiadają 5\% wszystkich praw głosu kontrahenta. Rozwinięte o kilka ustępów przepisy dotyczące cen transferowych zaczęły nabierać znaczenia dla przedsiębiorstw międzynarodowych, szczególnie w związku z określonymi metodami szacowania dochodów, do których przedsiębiorstwa musiały się dostosować, a także pierwszą regulacją traktującą o tym, kiedy podmioty są powiązane. Dzięki temu część przedsiębiorstw nie musiało się już obawiać możliwych doszacowań podatkowych, natomiast podmioty podlegające obowiązkowi dokumentacyjnemu musiały stawić czoła nowym wymogom.

W 2001 roku do polskich przepisów prawnych wprowadzono obowiązek dokumentacyjny dla podmiotów powiązanych, uzupełniając ustawę o podatku dochodowym od osób prawnych artykułem 9a, który wskazywał, kiedy taki obowiązek powstaje oraz co taka dokumentacja powinna zawierać. Jednocześnie wprowadzono $50 \%$ stawkę sankcyjną, która ma zastosowanie, jeżeli podatnik 
nie przekaże $\mathrm{w}$ określonym terminie dokumentacji z podmiotem powiązanym, a organy stwierdzą, że zaniżył on podstawę opodatkowania [Ustawa z dnia 9 czerwca 2000 r. ...].

Wraz z uzyskaniem członkostwa w Unii Europejskiej przez Polskę w 2004 roku, pojawiło się wiele zmian w polskim systemie podatkowym. Umożliwiono zawarcie uprzedniego porozumienia w zakresie cen transferowych dzięki wprowadzeniu działu IIa w Ordynacji podatkowej w 2006 roku [Ustawa z dnia 30 czerwca 2005 r. .... Zdecydowanie ułatwiło to funkcjonowanie podmiotom gospodarczym, które podjęły decyzję o zawarciu takiego porozumienia.

\section{EFEKTY GOSPODARCZE NOWYCH REGULACJI W ZAKRESIE CEN TRANSFEROWYCH W POLSCE}

Od początku 2017 roku zaczęły obowiązywać nowe przepisy w zakresie cen transferowych [Ustawa z dnia 9 października 2015 r. ...]. Wspomniane przepisy związane są ze zmianami w prawie unijnym, których celem jest znalezienie wspólnego dla krajów Unii Europejskiej podejścia związanego z zakresem wymaganych dokumentacji między podmiotami powiązanymi.

Wymagania w cenach transferowych uległy znaczącym zmianom, wpływając na funkcjonowanie małych, średnich i dużych przedsiębiorstw. Zmianie uległo samo określenie podmiotów powiązanych. Określane nimi są jednostki posiadające $25 \%$ [Ustawa z dnia 26 października 2016 r. ..., art. 11] udziału bezpośredniego lub pośredniego w kapitale innego podmiotu. Dotychczasowy limit wynosił 5\%, a więc część podmiotów nie będzie podlegała przepisom odnoszącym się do cen transferowych i zostaną wykluczone $\mathrm{z}$ obowiązku sporządzania dokumentacji cen transferowych. Nie uległy zmianie natomiast pozostałe powiązania (udział w zarządzaniu lub kontrola, powiązania o charakterze rodzinnym).

Kolejną zmianą jest nowy zakres podmiotowy oraz przedmiotowy odnośnie obowiązku sporządzania dokumentacji cen transferowych. Dotychczas brano pod uwagę transakcje, których wartość przekraczała 100 tys. euro (dla niektórych transakcji 50 tys. euro). Zastąpiono to podejście biorąc pod uwagę osiągane przychody lub koszty. Zależnie od uzyskanych w poprzednim roku przychodów lub kosztów i przekraczanych progów wartości transakcji będzie ustalany obowiązek dokumentacyjny. Z obowiązku dokumentacyjnego wyłączone zostały podmioty, których przychody lub koszty w poprzednim roku nie przekroczyły 2 mln euro [Ustawa z dnia 26 października 2016 r. ..., art. 9a].

Przedsiębiorstwa, których przychody lub koszty przekroczą 2 mln euro podlegają obowiązkowi dokumentacyjnemu według trzystopniowej skali. Jednostki, które przekroczą wartość 2 mln euro będą zobowiązane do przygotowania tzw. local file. Zawarte $\mathrm{w}$ nim informacje powinny przedstawiać strony transakcji, 
przedmiot ich działalności oraz metodę kalkulacji wartości transakcji. Następnie podmioty, który przekroczą $10 \mathrm{mln}$ euro, będą dodatkowo zobowiązane do przygotowania analizy porównawczej, która uzasadni rynkowość transakcji objętych obowiązkiem dokumentacyjnym. Dodatkowo zobowiązani są do złożenia uproszczonego sprawozdania $\mathrm{w}$ sprawie transakcji oraz innych zdarzeń $\mathrm{z}$ podmiotami powiązanymi razem z zeznaniem podatkowym. W przypadku przedsiębiorstw, które przekroczą $\mathrm{w}$ poprzednim roku kwotę 20 mln euro przychodów lub kosztów, powstaje również obowiązek przygotowania tzw. master file, gdzie podmiot powinien zawrzeć informacje o funkcjonowaniu całej grupy podmiotów powiązanych. Jednostki przekraczające przychody skonsolidowane powyżej $750 \mathrm{mln}$ euro są zobowiązane do przygotowywania tzw. country-by-country [Ustawa z dnia 26 października 2016 r. ..., art. 9a].

Biorąc pod uwagę powyższe zmiany, małe oraz średnie przedsiębiorstwa zostaną zwolnione $\mathrm{z}$ obowiązku sporządzania dokumentacji cen transferowych. Dzięki ustaleniu progu na poziomie $2 \mathrm{mln}$ euro zwolnione zostają najmniejsze podmioty z obowiązku dokumentacyjnego, umożliwiając im ograniczenie kosztów oraz obciążeń administracyjnych. Zmniejsza się poziom biurokracji, którym obciążone jest przedsiębiorstwo, a dzięki temu może się skupić na rozwoju i maksymalizacji przychodów.

Natomiast największe podmioty muszą przedstawiać w dokumentacji więcej informacji niż dotychczas. Dla jednostek rzetelnych i uczciwych rozszerzony zakres dokumentacji nie powinien stanowić większego problemu, zaś podmioty przekłamujące warunki swoich transakcji będą zobowiązane do korekty sprawozdań i dopłaty różnicy podatkowej. W przypadku braku przedstawienia takiej dokumentacji nakładana jest stawka sankcyjna w wysokości 50\% w przypadku rozpoznania różnicy między dochodem zadeklarowanym a ustalonym przez organ podatkowy [Ustawa $z$ dnia 26 października 2016 r. ..., art. 9a].

Pomimo zmniejszenia zakresu podmiotowego przygotowywanych dokumentacji cen transferowych, wpływy z ich tytułu szacunkowo wzrosły o $25 \%$ (z 2 mld do 2,5 mld zł) [www1]. Przekłada się to na zmniejszanie szarej strefy [Szara strefa $w$ polskiej gospodarce, 2016: 6], a co za tym idzie zwiększenie dochodów budżetu państwa, powstrzymywanie symptomów inflacyjnych oraz podniesienie poziomu pomocy socjalnej. Zwiększające się wpływy umożliwiają jednocześnie zmniejszenie obciążeń podatkowych firm oraz osób fizycznych płacących uczciwie podatki. W konsekwencji, malejący fiskalizm może przełożyć się na zawężającą się szarą strefę. Małe i średnie przedsiębiorstwa stanowią zdecydowaną większość na polskim rynku, więc malejący zakres podmiotowy dokumentacji, a jednocześnie zwiększające się wpływy z cen transferowych, przynoszą wymierne korzyści dla legalnie działających podatników.

Rozszerzony obowiązek dokumentacyjny przekłada się na wspieranie uczciwej konkurencji podmiotów gospodarczych. Dzięki temu małe i średnie 
firmy, które wywiązują się z obciążeń podatkowych otrzymują większą swobodę konkurencyjną na wolnym rynku również z dużymi firmami, które mogły dotychczas zakłamywać wartości swoich transakcji.

W związku z ograniczaniem szarej strefy możliwe jest przyspieszenie postępu technologicznego [System stworzony od podstaw..., 2014: 38], a tym samym rozwój gospodarki i jakości życia polskich podatników. Uszczelnianie w cenach transferowych ma również przełożenie na poziom wykształcenia pracowników poszczególnych jednostek, bowiem podmioty działające w szarej strefie mają tendencje do zatrudniania osób o niskich kwalifikacjach, natomiast podmioty legalnie funkcjonujące szukają dobrej jakości zasobów ludzkich o jak najwyższych kwalifikacjach. Dzięki temu przekłada się to również na lepszą jakość produkowanych dóbr, które ostatecznie trafiają do konsumentów. W przypadku podmiotów powiązanych może przełożyć się to na lepsze funkcjonowanie całej grupy.

Zwiększenie udziału legalnych przedsiębiorstw w rynku, wspieranie uczciwej konkurencji oraz poprawienie warunków funkcjonowania przedsiębiorstw są jednym $z$ priorytetów resortu finansów [www2], a uszczelnianie cen transferowych oraz podniesienie limitów powodują, że małe i średnie przedsiębiorstwa mogą łatwiej osiągać zyski i przyczyniać się do rozwoju technologicznego, który przekłada się na wzrost PKB, pozytywnie wpływając na rozwój gospodarczy.

Zwiększenie wpływów budżetu państwa w zakresie cen transferowych daje możliwość stosowania łagodniejszej polityki gospodarczej. Wykrycie podmiotów nie płacących podatków pozwoli na obniżenie stawek, a tym samym poprawienie warunków tych jednostek, które dotychczas je płaciły.

\section{PODSUMOWANIE}

Państwo stosuje określoną politykę podatkową w taki sposób, by maksymalizować swoje dochody oraz maksymalizować wzrost gospodarczy. Ceny transferowe i zmiany $\mathrm{w}$ ich zakresie wywierają istotny wpływ na sytuację podatników. Stały się one przedmiotem coraz większego zainteresowania organów podatkowych w ostatnich latach. Aktualnie sposób podejścia do opodatkowania dochodów związanych z prowadzoną działalnością gospodarczą stanowią istotne wyzwanie dla doktryny podatkowej obowiązującej w Polsce. Dotyczy to więc jednocześnie cen transferowych, które są najbardziej problematyczne [Polski system podatkowy, 2017: 5]. Istotne jest wypracowanie takich przepisów, które będą umożliwiały efektywne reinwestowanie środków przez przedsiębiorstwa oraz nie będą traciły one szansy dodatkowego zysku ze względu na uciążliwe zobowiązania dokumentacyjne, niejasności oraz niespójności w polskim prawie podatkowym. Najnowsze przepisy prawne przełożyły się na zmniejszenie obo- 
wiązków podatkowych małych i średnich przedsiębiorstw, jednocześnie zwiększając wpływy do budżetu państwa dzięki poszerzeniu obowiązku dokumentacyjnego dla podmiotów, które zobowiązane są do jej przygotowania. Zmiany te przynoszą pozytywne skutki dla polskiej gospodarki, pozwalają na ograniczanie szarej strefy, chroniąc podatników oraz poprawiając jakość życia obywateli państwa.

\section{BIBLIOGRAFIA}

Bylicki L., 2016, Polski system podatkowy - zagadnienia ogólne, [w:] J. Grzywacz (red.), P. Kaczmarczyk, Zeszyty Naukowe PWSZ w Płocku. Nauki Ekonomiczne, T. 23, Państwowa Wyższa Szkoła Zawodowa w Płocku, Płock.

Czubakowska K., Grodzińska A., 2013, Ocena systemu podatkowego w opinii przedsiębiorców z województwa zachodniopomorskiego, [w:] T. Kiziukiewicz (red), Problemy współczesnej rachunkowości. Tom 2, Wydawnictwo Naukowe Uniwersytetu Szczecińskiego, Szczecin

Dekret z dnia 8 stycznia 1946 r. o podatku dochodowym.

Galwas B., Pawłowski L., Taduesiewicz R., 2013, Siła i słabości szkolnictwa wyższego w Polsce, „Przyszłość. Świat-Europa-Polska”, nr 1.

Gomułowicz A., 1989, Zasada sprawiedliwości w polskim systemie podatkowym, [w:] T. Rabska (red.), W. Przybylska-Kapuścińska, R. Drozdowski, M. Smolak, Ruch Prawniczy, Ekonomiczny i Socjologiczny 51, z. 3, Wydział Prawa i Administracji UAM, Poznań.

Możyłowski P., 2007, Wpływ podatków na wzrost gospodarczy, [w:] D. Kopycińska (red.), Funkcjonowanie gospodarki polskiej $w$ warunkach integracji i globalizacji, Katedra Mikroekonomii Uniwersytetu Szczecińskiego, Szczecin.

Owczarczyk-Szpakowska G., 2009, Zarządzanie przez podatki, Polskie Stowarzyszenie Zarządzania Wiedzą, Bydgoszcz.

Owsiak S., 2016, System podatkowy Polski w okresie transformacji - próba oceny, „Annales Universitatis Mariae Curie-Skłodowska Lublin - Polonia", Vol. L, 1.

Raport firmy EY, 2014, System stworzony od podstaw, czyli prawdziwa historia 25-lecia polskich podatków.

Raport firmy Grand Thornton, 2017, Podatki w Polsce.

Raport firmy KPMG, 2017, Polski system podatkowy.

Raport Instytutu Badań Nad Gospodarką Rynkową, 2016, Szara strefa w polskiej gospodarce.

Raport Związku Przedsiębiorców i Pracodawców, 2014, Analiza ZPP: Powody i skutki wadliwego systemu podatkowego, Warszawa.

Rosiński R., 2010, Podatek i jego klasyfikacja w polskim systemie podatkowym, [w:] G. Przekota (red.), Zeszyty Naukowe Wydziału Nauk Ekonomicznych Politechniki Koszalińskiej, nr 14, Wydawnictwo Uczelniane Politechniki Koszalińskiej, Koszalin.

Sojak S., 2016, Ceny transferowe. Teoria i praktyka, Wydawnictwo Naukowe PWN, Warszawa.

Szczodrowski G., 2007, Polski system podatkowy, Wydawnictwo Naukowe PWN, Warszawa.

Szołno-Koguc J., 2016, Dylematy sprawiedliwości podatkowej - równość i powszechność opodatkowania a przywileje podatkowe, [w:] J. Harasim (red.), Studia Ekonomiczne. Zeszyty Naukowe Uniwersytetu Ekonomicznego w Katowicach, Wydawnictwo Uniwersytetu Ekonomicznego w Katowicach, Katowice.

Ustawa z dnia 15 lutego 1992 r. o podatku dochodowym od osób prawnych oraz o zmianie niektórych ustaw regulujących zasady opodatkowania, Dz.U. 1992, nr 21, poz. 86. 
Ustawa z dnia 18 marca 1935 r. o zmianie ustawy o państwowym podatku dochodowym, Dz.U. 1935, nr 24, poz. 162.

Ustawa z dnia 21 listopada 1996 r. o zmianie ustawy o podatku dochodowym od osób prawnych, Dz.U. 1996, nr 137, poz. 638.

Ustawa z dnia 26 października 2016 r. o podatku dochodowym od osób prawnych, Dz.U. 2016, nr 0, poz. 1888 .

Ustawa z dnia 30 czerwca 2005 r. o zmianie ustawy - Ordynacja podatkowa oraz o zmianie niektórych innych ustaw, Dz.U. 2005, nr 143, poz. 1199.

Ustawa z dnia 9 czerwca 2000 r. o zmianie ustawy o podatku dochodowym od osób prawnych, Dz.U. 2000, nr 60, poz. 700.

[www1] https://www.podatki.biz/artykuly/podatki-2017-wplywy-z-cen-transferowych-wiekszeod-oczekiwan_16_36435.htm [dostęp 30.05.2018].

[www2] http://www.portalspozywczy.pl/technologie/wiadomosci/rzad-zaakceptowal-projektmajacy-sprzyjac-uczciwej-konkurencji,155794.html [dostęp 30.05.2018].

Żabiński A, Pohulak-Żołędowska E., 2016, Fiskalne uwarunkowania budowy systemu podatkowego w wybranych krajach, „Prace Naukowe Uniwersytetu Ekonomicznego we Wrocławiu”, nr 451.

\title{
SEALING THE POLISH TAX SYSTEM IN THE FIELD OF TRANSFER PRICING AS A METHOD OF TAXPAYERS' PROTECTION
}

\begin{abstract}
Recently, there have been major changes in transfer pricing increasing the documentation requirements of many enterprises. Like any legal changes, they have certain effects. Transfer pricing history in Poland dates back to the first half of the twentieth century and you can see the successive development of regulations in their scope. The recently introduced provisions on transfer pricing contributed to a change in the scope of duties for individual groups of taxpayers. This work will analyze changes in transfer pricing and their impact on taxpayers' obligations.
\end{abstract}

Keywords: tax system, transfer pricing, taxpayers' protection. 